\title{
BANJARESE GREETINGS SYSTEM IN DISTRICT KAPUAS OF CENTRAL KALIMANTAN
}

\author{
Indra Perdana ${ }^{1}$, Achmad HP $^{2}$ \\ ${ }^{1}$ Universitas Negeri Palangka Raya, Indonesia \\ ${ }^{2}$ Universitas Negeri Jakarta, Indonesia \\ 1indraperdana86@gmail.com, ªchmad.hp@unj.ac.id
}

\begin{abstract}
Research on the study of the use of greeting in Banjarese which stay in Kapuas District of Central Borneo.This Research focused to describe the greeting word used by the people, particularly the greeting word in Banjarese used by the first generetion in Kapuas. The research method used is descriptive qualitative. Data collection by observation with a look at, involved notes. Sources of research data used is the preference of all speech that is displayed by 1) Aged over 30 years, 2) Native language studied. 3) Knowing its own culture, 4) The Banjarese are the first generation derived from Banjarmasin, 5) The Banjarese who had lived in Kapuas. Based on this research shows 1) Greetings kinship to greet our parents (father + mother $) \rightarrow(+$ Uma Abah); Greetings kinship parents to greet our father and mother (grandfather + grandmother $) \rightarrow(k a i+$ nini); Greetings kinship to greet parents our grandparents are corrected; Greetings kinship to greet both parents protested was waring; Greetings kinship to say hello (brother + sister) $\rightarrow$ (kaka + ading). Greetings kinship to say hello if our children have children (grandchildren) $\rightarrow$ (grandchildren); Greetings kinship to say hello if we have children and grandchildren is a great-grandfather. And 2) The system of daily greeting, to call people who may be called ikam lifetime, lives. I use the word, unda to appoint themselves. As for honor or call older used the word pian, and said ulun to appoint its own self.
\end{abstract}

Keywords: Banjarese; Greetings; family.

Local language is one language that is used as a means of communication between members of the community (intraetnik). In some regional languages in Indonesia to declare a particular purpose provided a number of different lexical items. For example in the language Maanyan now known word for word itati, hintekina that its use has been established and agreed upon by members of the community. The existence of different lexical items was made possible by the social structure of the community who know certain strata. The function of regional languages according to Halim (1983: 34) is as (1) the symbol of regional pride; (2) the symbol of regional identity; (3) means of transportation in the family and local community.

Said greeting the form of words used to greet, reprimand, calling a second person, or a person who was invited to speak. Kridalaksana (1982: 14) states that the word greeting is morpheme, word, or phrase that is used to refer to each other in situations of conversation vary depending on the nature of the relationship between the speaker.

Kinship in a language arising from the need to express oneself communicatively position in a family. Kinship is a social units consisting of several families who have blood ties or marriage relationship. Kinship members consisting of father, mother, son, daughter, grandchild, brother, sister, uncle, aunt, grandfather, grandmother and so on. Mahmud (2003: 15) states that kinship is a form of social relations that occur 
because of heredity (consanguinity) and marriage (affinity). Someone called related when there consanguinity or affinity marriage. Syafyahya (2000: 7) states that a person is said to be relatives of consanguinity or if there is a direct linkage and linkage of marriage or not langsung.Oleh Therefore, kinship plays an important role in fostering ties and a sense of community groups such as kinship indicates the status of its members. The term shows the differences in the roles of each member, either in conjunction with offspring (consanguinity) and in relation to marriage (affinity).

Kinship based on the same lineage as kinship that exists because of the incestuous relationship. Kinship is seen berdasarkangaris descendants of descendants embraced by a society. As with the kinship based on marriage is a kinship that exists after the marriage. In determining the relative by marriage can be seen from the first lineage. Society is wearing mother or matrilineal lineage then the father who became relatives by marriage line. However, people who wear paternal line then the mother who became relatives by marriage.

Each region, whether kinship by descent or kinship based on marriage has a different greeting system. The greeting words are used to maintain the alliance system in the language in certain areas. Therefore, according to the kinship greeting should be preserved to avoid extinction. The high globalization and social mobility, as well as the expansion of the mass media to rural areas such as TV, radio, and newspapers have influenced the development of the greeting words on a region.

Accordingly, Banjar language as one of the local languages which are in Indonesia, also serves as a communication tool within the family and society Banjar. Associated with it as well, the authors interested in studying the language greeting Banjar system problems. The title of this research is: "Greetings System Language Banjar Kapuas".

Research on greeting involves a direct relationship with the use of language speakers, in other words, the system greeting put pressure on relations with the speakers of languages spoken in accordance with the conditions or situations and environments where the greeting. In particular formulation of the problem of this research is as follows. 1. How does the system greeting kinship Banjar Kapuas? 2. How greeting kinship system Banjar Kapuas from highest to lowest kedududukannya in the family? 3. How does the system greeting everyday language Banjar Kapuas?

Banjar language greeting system research Kapuas This includes the scope of sociolinguistic research. Therefore, the theory used is the theory of sociolinguistics, which refers to the basic prinsif sociolinguistics see language as a means of communication in a society that seeks to explain the question "who is talking to whom using what language is and where and with what purpose?" (Fishman, 1972: 15). Here illustrated clearly that sociolinguistics does not focus on linguistic phenomenon, but also focus on behavior, attitude, language, behavior of the real against the language and user language (Fishman, 1972: 2).

Sociolinguistic research on this shows how diverse color greeting in the language system. The assortment is determined by the regional dialect, social dialect, variations in language, the nature of the relationship between the perpetrator (intimate, unusual, formal, reciprocal, nonresiprokal) as well as factors multilingualism in Indonesia (Kridalaksana, 1982: 15).

The General Theory of Forms Greetings Understanding forms of address used in this study is a word or phrase used to describe and memamanggil actors in a language 
events. The perpetrator is the speaker (the perpetrator), hereinafter referred penyapa, who talk (both actors), hereinafter referred pesapa and called in the conversation (three actors). It can be a form of address pronouns, proper names, kinship terms, words dieksis or pointer, nominal, and tanujud (characteristic zero or zero) (Kridalaksana, 1982: 14).

\section{Context The use Greetings}

Pragmatics in essence can be either a science or a theory called pragmatic science, can also be a skill called pragmatic skills is the ability to use language that is adapted to the context (Sudaryanto, 1985: 5). Essentially pragmatic theory that examined the relationship between languages in the context of the use of these languages have a scope broad enough study. The scope of the pragmatic study include: (1) Variation of language; (2) deixis; (3) conversational implicatures; (4) prejudice; (5) the followspeaking; and (6) the situation conversation (Suyono, 1990: 60).

The word greeting is one of pragmatic studies, particularly related to the topic of deixis. Deixis are words or phrases that do not have The reference fixed because it depends on the context (Purwo, 1982: 34). There are five kinds of deixis, namely deixis person, place, time, discourse, and social. The word greeting including social deixis, namely the use of the word / phrase that led to the emergence of ethical propriety speak or speaking.

From the above description, it can be concluded that the context of the use of the greeting can be seen from two things, namely the situational context and linguistic context. Situational context consists of the cultural context and the immediate context; cultural context depends on personality, attitude and behavior of public speakers, while the immediate context can be seen from the variable sociolinguistic who are related to speech that is: (1) who the speaker, (2) who the recipient, (3) the topic, (4) where event occurs utterance, (5) the means used to deliver the speech for example, directly or indirectly (through the mail), (6) code, the language or dialect used, and (7) the purpose of the conversation.

\section{Theory Selection Techniques Use Form Greetings}

The word greeting in Indonesian there are nine types as noted below: (1) pronouns (like I, you, you, he, and others; (2) the name of the self (the person's name that is used for all the actors); (3) the term kinship (father, mother, uncle, brother, and so on, as the word greeting kin terms are not only used to the extent those are related, but also with others); (4) the title and rank (such as doctors, nurses, teachers and etc.); (5) the form pe $+\mathrm{V}$ (erbal) or said actors (such as readers, writers, viewers, passengers, etc.); (6) forms $\mathrm{N}$ (ominal) + I (like my Lord, my sister, my love, and others; (7) the words deixis or pointer (that is there, here, this, that); (8) the nominal or word dibendakan (like lord, lady, mistress, and so on); (9) characteristic zero or zero (for example, people who want to say where "Where?" said greeting relatives are not mentioned but understood people (Kridalaksana, 1982: 14).

\section{METHODS}

The method used in this research is descriptive method. Sudaryanto (in Sudartini 2010: 5) states that the descriptive terms that suggest that research conducted solely 
based on the facts or phenomena that are empirically-speakers live in the speakers. The terms of the descriptive method, the method suggested that research be conducted by researchers solely based on the fact that existing and phenomena indeed be living in speakers-speakers. In this case, the research conducted is useful to provide an overview of Madura language greeting interference by incest.

This study is a qualitative form that does not provide stimulation to the object to be studied. Research is done naturally and explain what is happening in the field. According Satori (2011: 25) qualitative research is a research approach that reveal certain social situations to describe reality correctly, formed by the words based on the techniques of collecting and analyzing relevant data and derived from a natural situation. Thus, the reason for the selection was a qualitative descriptive method because this method is seen to provide an objective picture of the research so as to provide the facts fit the subject and object.

The data in this study is Greeting in Banjar language based kinship and amendments contained in Kapuas. The data source of this research is Banjarese which stay in Kapuas. Data obtained by interviewing informants in accordance with the selection criteria for informants. The terms of the selection of informants in this study as follows: 1) Aged over 30 years; 2) Native language studied; 3) Knowing its own culture; 4) The Banjarese are the first generation derived from Banjarmasin; 5) The Banjarese who had lived in Kapuas.

Data collection techniques used in this research is interview or participant observation. Interview or participant observation is a joint effort of the activities to see, hear, and ask (Moleong, 2012: 157). Researchers in addition to interviewing the informant, also see the phenomenon that occurs within the Madura language users.

According Moleong (2012: 186) "interview is a conversation with a purpose. The conversation was conducted by the two parties, namely the interviewer (interviewer) who asked questions and interviewees (interviewee), which provides answers to the question ". Interviews conducted by researchers in this study is a structured interview. In this case, researchers have set the questions that will be posed to the informants. The main data collection tool is the researcher as a key instrument in the study because as planning, implementing, collecting data, and the reporting of research results. The data collection tool to support this research that digital cameras, voice recorders, pen, list of questions.

\section{RESULTS}

1. System Greetings Kinship Banjar

a. Ancestry Mr.

\begin{tabular}{cll}
\hline No. & Unsur kerabat & Bentuk sapaan \\
\hline 1 & Bapak & Abah \\
2 & Adik laki-laki bapak & Amang \\
3 & Kakak laki-laki bapak & Amang \\
4 & Kakak perempuan bapak & Acil \\
5 & Adik perempuan bapak & Acil \\
6 & Bapak kandung bapak & Kai \\
7 & Ibu kandung bapak & Nini \\
\hline
\end{tabular}


Native speakers of Banjar Kapuas to greet the natural father used the word direction, a younger brother and an older brother called by the same word that is Amang, sister and sister with the same word also is acil, for greeting natural father was kai , while for greeting mother ninny.

If in the form of a greeting speech which consists of two words into one word. For example:

$\mathrm{Abah} \rightarrow \mathrm{Bah}$

Amang $\rightarrow$ mang

Acil $\rightarrow$ Cil

Nini $\rightarrow$ ni

Example: Bah, Amang Sudah tulak kamana?

Father, uncle to go where?

\section{b. Ancestry Mother}

Table 2. System Greetings Ego Against Mother Mother and Brother

\begin{tabular}{cll}
\hline No. & Unsur Kerabat & Bentuk Sapaan \\
\hline 1 & Ibu & Uma, mama \\
2 & Kakak perempuan ibu & Acil \\
3 & Kakak laki-laki ibu & Amang \\
4 & Adik laki-laki ibu & Amang \\
5 & Adik perempuan ibu & Acil \\
6 & Nenek & Nini \\
7 & Kakek & Kai \\
\hline
\end{tabular}

If in the form of a greeting speech which consists of two words into one word. For example:

Mama $\rightarrow$ Ma

Amang $\rightarrow$ mang

Acil $\rightarrow$ Cil

nini $\rightarrow$ ni

Example: Ma, ulun isuk bamalam di wadah nini.

Mother, I stay at grandma's house tomorrow.

Banjar native speakers in Kapuas to greet the mother uses the word uma, mama, mother's sister called acil, older brother from mother called Amang, sister from mother also called acil. Greetings for the biological grandmother nini, while greeting to the biological grandparents kai.

\section{c. Greetings system Ego Against Sibling}

Table 3. System Greetings Ego Against Sibling

\begin{tabular}{cll}
\hline No. & Unsur Kerabat & Bentuk Sapaan \\
\hline 1 & Kakak kandung laki-laki & Kaka/kaka laki \\
2 & Adik kandung laki-laki & Ading/ading laki \\
3 & Kakak kandung perempuan & Kaka/kaka bini \\
4 & Adik kandung perempuan & Ading/Ading bini \\
\hline
\end{tabular}


Banjar native speakers in Kapuas to greet the elder brother of men use the word $k a k a$, the younger brother of men called ading, older sibling called kaka bini, women younger brother called ading bini.

If in the form of a greeting speech which consists of two words into one word. For example:

Kaka $\mathrm{Ka} \rightarrow$

ading ding $\rightarrow$

Example: Ka, pian tulak datang mama jam barapa?

Brother, when you going to see Mom?

\section{d. Greetings system Ego Wife and Relatives Against Wife}

Table 4. System Greetings Ego Against Wife And Relatives Wife

\begin{tabular}{cll}
\hline No. & Unsur Kerabat & Bentuk Sapaan \\
\hline 1 & Istri & Bini \\
2 & Kakak laki-laki istri & Kaka ipar laki/kaka ipar binian \\
3 & Kakak perempuan istri & Kaka ipar bini/kaka ipar binian \\
4 & Adik perempuan istri & Ading ipar bini \\
5 & Adik laki-laki istri & Ading ipar laki \\
6 & Bapak istri & Mintuha laki \\
7 & Ibu istri & Mintuha bini \\
\hline
\end{tabular}

Banjar native speakers Kapuas to greet his wife use the word wife, brother-inlaw's wife called kaka male / kaka-law males, wife's sister-in-law called ading chant, the father called mintuha man's wife. The wife's mother called mintuha chant. Example: Mintuha chant was tulak nukar what?

Women-in-law had gone to buy what?

\section{e. Greetings system Ego Relatives Against Husband and Husband}

Table 5. System Ego Greetings Relatives Against Husband and Husband

\begin{tabular}{cll}
\hline No. & Unsur kerabat & Bentuk sapaan \\
\hline 1 & Suami & Laki \\
2 & Kakak laki-laki suami & Kaka ipar laki \\
3 & Kakak perempuan suami & Kaka ipar bini \\
4 & Adik perempuan suami & Ading ipar bini \\
5 & Adik laki-laki suami & Ading ipar laki \\
6 & Ibu suami & Mintuha bini \\
7 & bapak suami & Mintuha laki \\
\hline
\end{tabular}

Native speakers of Banjar Kapuas to greet her husband uses the word man, brother husband called kaka chant / kaka-law binian, brother husband called ading law male / ading-law males, husbands mother called mintuha chant, while the father of the husband called mintuha men.

Beyond the above table also obtained the call data for the brother of the father or the mother. The oldest brother called Julak, the second brother called Gulu, the middle brother of the father and mother are called Angah, and the other is usually called Pakacil (uncle) and Makacil (aunt). To call a brother of kai and nini same, as well as for you datu.

Example: Makacil pian lagi bawa apa?

Aunt bring what? 


\section{DISCUSSION}

\section{System Greetings Kinship Language Banjar Who Lived in Kapuas of Highest} Lowest Until The Position in the Family Greetings SYSTEMS SOCIETY BANJAR

Such as kinship systems generally, Banjar community recognize certain terms as the call in the family confluence of the position of the highest to the lowest in the family.

Under the scheme is centered on the EGO as the denominator.

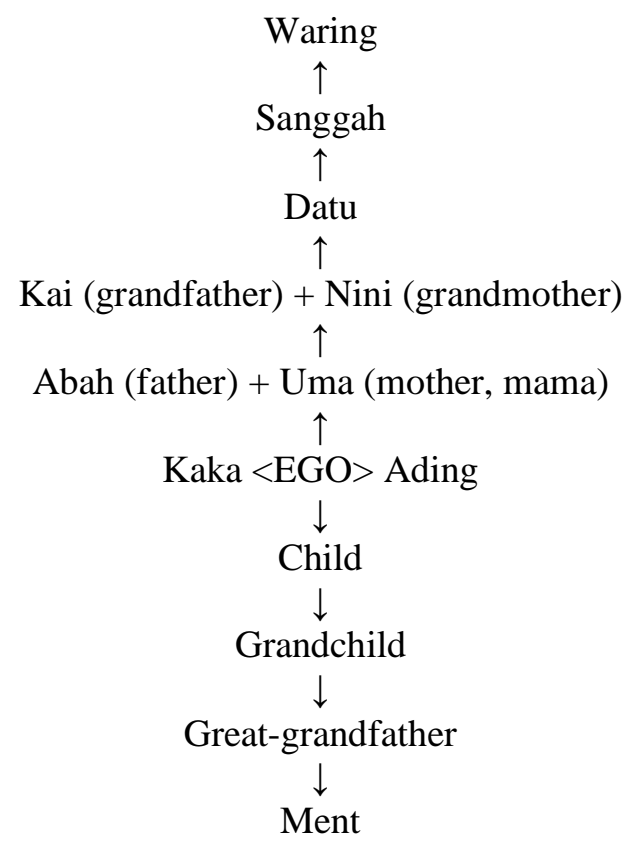

Description scheme:

1. Greetings kinship to greet our parents (father + mother $) \rightarrow($ Abah + Uma)

2. Greetings kinship parents to greet our father and mother (grandfather + grandmother) $\rightarrow$ (kai + nini).

3. Greetings kinship to greet parents grandparents we are sanggah

4. Greetings kinship to greet both parents sanggah is waring

5. Greetings kinship to say hello (brother + sister $) \rightarrow$ (kaka + ading).

6 . Greetings kinship to say hello if our children have children (grandchildren) $\rightarrow$ (grandchildren).

7. Greetings kinship to say hello if we have children and grandchildren is a greatgrandfather.

Example: Cu Ikam handak makan apa?

You want to eat anything $\mathrm{Cu}$ ?

\section{System Greetings Everyday Language Banjar Kapuas}

System greeting everyday language Banjar Kapuas is a greeting that is used every day. From the data obtained in the field, to call people who may be called ikam 
lifetime, lives. I use the word, unda to appoint themselves. As for honor or call older used the word pian, and said ulun to appoint its own self.

Note:

1. The word lives which means 'you' is the language between peers who are very familiar; in some areas Banjar considered rude.

2. unda word meaning 'I', I was a language that is very familiar among the same age; in some areas Banjar considered rude.

\section{CONCLUSION}

Based on data analysis has been done on the discussion can be concluded greeting system Kapuas Banjar language can be grouped into two general categories:

1. Greeting kinship system

Greetings kinship to greet our parents (father + mother) $\rightarrow$ (+ Uma Abah); Greetings kinship parents to greet our father and mother (grandfather + grandmother)

$\rightarrow$ (kai + nini); Greetings kinship to greet parents our grandparents are corrected; Greetings kinship to greet both parents protested was waring; Greetings kinship to say hello (brother + sister) $\rightarrow$ (kaka + ading). Greetings kinship to say hello if our children have children (grandchildren) $\rightarrow$ (grandchildren); Greetings kinship to say hello if we have children and grandchildren is a great-grandfather.

2. The system of daily greeting.

To call people who may be called ikam lifetime, lives. I use the word, unda to appoint themselves. As for honor or call older used the word pian, and said ulun to appoint its own self.

\section{REFERENCES}

Bogdan, Robert and Steven L.Taylor. (1984). Introduction to Qualitative Research to the Social Scinnes. New York: John and Sons Inc.

Emzir. Metodologi Penelitian Kualitatif dan Kuantitatif. (2008). Jakarta: PT Raja Grafindo Persada.

Fishman, J.A. ed. (1972). Reading in the Sociology of Language. The Hague: Mounton.

Halim, Amran. (1984). Politik Bahasa Nasional. Jakarta: Pusat Pembinaan dan Pengembangan Bahasa.

Ibrahim, Abd Syukur. (1993). Sosiolinguistik: Sajian, Tujuan, Pendekatan dan Problema. Surabaya: Usaha Nasional.

Kridalaksana, Harimukti. (1982). Fungsi dan Sikap Bahasa. Flores: Nusa Indah.

Leech, Geoffrey. 1993. Prinsip-prinsip pragmatik(terjemahan). Jakarta: Universitas Indonesia. 
Mahmud, dkk. (2003). Sistem Sapaan Bahasa Simeulue. Jakarta: Pusat Bahasa.

Nawawi, Hadari. (1994). Penelitian Terapan. Yogyakarta: Yogyakarta University Press.

Sudariyanto. (1998). Metode Linguistik. Yogyakarta: Yogyakarta University Press.

Sumarsono dan Partana. (2002). Sosiolinguistik. Jogjakarta: Andi Offset.

Suyono. (1990). Pragmatik Dasar-dasar Pengajarannya. Malang: YAS.

Yule, George. (2006). Pragmatik (Terjemahan Indah Fajar Wahyuni). Yogyakarta: Pustaka Pelajar.

https://www.researchgate.net/publication/50515786_telaah_penggunaan_kata_sapa an_di_lingkungan_mahasiswa_jurusan_bahasa_indonesia_umm 